ACTA UNIVERSITATIS LODZIENSIS

FOLIA LITTERARIA POLONICA 4(34) 2016

http://dx.doi.org/10.18778/1505-9057.34.16

Grzegorz Zając*

\title{
(Nie)przyjemne zabawy wierszem pod okiem redaktora Naruszewicza
}

Pośród licznych, w różnych okolicznościach składanych, na ogół jednak dowodzących zadziwiająco bezkrytycznego stosunku do władcy, hołdów, których adresatem był u progu lat siedemdziesiątych XVIII stulecia Stanisław August Poniatowski, słowa Jana Albertrandiego, profesora jezuickiego Collegium Nobilium w Warszawie, jakich użył on, rozpoczynając wydawanie „Zabaw Przyjemnych i Pożytecznych" ", niczym nadzwyczajnym się nie wyróżniały. Górnolotne sformułowania na temat mądrości „łaskawym z wysokości tronu wejrzeniem obdarzonej” czy też trącące pedagogiczną rutyną uwagi o dostrzeżonej przez króla-patrona nauk ,potrzebie wydoskonalenia narodu” można by wręcz uznać za element kulturowego rytuału, nakazującego w imię światopoglądowego imperatywu, ale i okołodworskiej etykiety akcentować zasługi byłego stolnika litewskiego, zasiadającego wtedy od kilku już lat na polskim tronie.

Inaczej rzecz się miała z tymi fragmentami przedmowy, którą Albertrandi opatrzył pierwszy arkusz zakładanego przez siebie pisma, gdzie objaśniane były powody powołania „Zabaw...” do życia, z czym łączyła się eksplikacja głównego członu ich tytułu. Wychodząc od ocierającego się o sentencjonalność, acz niespecjalnie oryginalnego spostrzeżenia: „Zaprzątnąć ludzi każdy umie; zabawić, rzadki kto potrafi" - poprzednik Adama Naruszewicza na stanowisku redaktora elitarnego periodyku stwierdzał, iż „,rozerwanie myśli i wytchnienie po pracach życia prywatnego, czyli na publiczną usługę poświęconego, darem jest, z którym nader oszczędnie obchodzi się natura”. I to właśnie miało być wyzwaniem dla autora dopiero co opublikowanego tłumaczenia słynnej już wówczas powieści o przygodach Robinsona Crusoe, i jego, rekrutujących się głównie ze środowiska jezuitów, współpracowników. Wyzwaniem, którego podjęcie się było jednak wedle Albertrandiego o tyle łatwiejsze, o ile sprzyjały temu zmiany dokonujące

* Dr hab., Uniwersytet Jagielloński, Wydział Polonistyki, Katedra Historii Literatury Staropolskiej, ul. Gołębia 16,31-007 Kraków; e-mail: grzegorz.zajac@uj.edu.pl

${ }^{1}$ Kolejne fragmenty jego Przedmowy, zamieszczonej w „Zabawach Przyjemnych i Pożytecznych” 1770, t. 1, cz. 1, s. I-XI, cyt. za: ,Zabawy Przyjemne i Pożyteczne” (1770-1777). Wybór, oprac. i wstęp J. Platt, Zakład Narodowy im. Ossolińskich - Wydawnictwo, Wrocław 1968, s. 3-8. 
się w umysłach i postawach Polaków. Tak rozumianą odwagę twórców tygodnika warunkowało bowiem dojrzewające w nich przekonanie, że skutkiem „skłonności chwalebnej w narodzie górować poczynającej” „Zabawy...” będą miały odbiorcę; że, odpowiednio wykształcony i przygotowany do lektury, znajdzie on w nich to, co może pomóc w owym „rozerwaniu umysłu” - potrafił będzie należycie odczytać treści budujące przyjemnościowy walor pisma.

Emanujący z cytowanego powyżej wywodu entuzjazm w kwestii szybkiego wychodzenia poddanych Stanisława Augusta z przedoświeceniowej niepełnoletności przekładał się na zamiar zapewnienia potencjalnemu czytelnikowi rozrywki odpowiadającej jego predyspozycjom i oczekiwaniom, właściwej posarmackiej już obyczajowości². Gwarancją wysokiego poziomu tej rozrywki, a tym samym czymś, co sprawi, że tytułowe zabawy poprzez literaturę staną się rzeczywiście przyjemne, miały być - o czym donoszono w poprzedzającym ukazanie się pisma Uwiadomieniu - „rozmaitość i wybór materii”’ , z jaką mogliby obcować przedstawiciele idealizowanej przez Albertrandiego czytającej publiczności Rzeczpospolitej. Rychło okazało się jednak, że wskazywanego w tym samym anonsie „ulżenia” rozmaitość ta przynosić im wcale nie musiała, niezależnie od estetycznego poloru i różnorako dającej się postrzegać pożyteczności poszczególnych tekstów. Wpływ miała na to niewątpliwie zaostrzająca się w kraju sytuacja polityczna, będąca skutkiem coraz intensywniejszej penetracji struktur państwa przez przyszłych zaborców, z Rosją na czele, i związanej z tym radykalizacji środowisk przeciwnych polityce dworu królewskiego, prowadzącej ich zdaniem do utraty narodowej suwerenności. Wobec zacieśniających się po przejęciu redakcji „Zabaw...” przez Naruszewicza w początkach 1771 roku związków pisma z otoczeniem Stanisława Augusta, czego rezultatem było zyskiwanie przez nie charakteru swoistej trybuny tego środowiska (Elżbieta Aleksandrowska używa w tym kontekście takich między innymi określeń, jak „poetycki biuletyn wydarzeń dworu i bliskiego mu towarzystwa stołecznego” czy „literacka tuba propagandowa królewskiego programu reform"4), nie mogło dziwić, że zwłaszcza poczynania konfederatów barskich, w tym oczywiście brawurowe uprowadzenie przez nich króla, znajdowały tam odzwierciedlenie, będąc przedmiotem tyleż pełnych wzburzenia, ile podszytych niepokojem o dalszy los Polski wynurzeń wierszem.

O jednym z takich utworów przyjdzie powiedzieć więcej w dalszej części artykułu, w tym miejscu warto natomiast zwrócić uwagę na inne jeszcze zjawi-

${ }^{2} \mathrm{~W}$ odpowiednim miejscu autor stwierdzał: „Więc to tylko dla nas zostawało, natężonemu Czytelnika umysłowi spoczynek jaki po zaprzątającym jego pracowitym czytaniu obmyślić, a spoczynek godny przeszłej jego pracy, godny chwalebnej skłonności”. Tamże, s. 6.

${ }^{3}$ Cyt. za: tamże, s. XX. Uwiadomienie to ukazało się w: Suplement do „Wiadomości Warszawskich" 1770, nr 1 (z 3 stycznia).

${ }^{4}$ E. Aleksandrowska, ,,Zabawy Przyjemne i Pożyteczne” 1770-1777. Monografia bibliograficzna, Wydawnictwo Instytutu Badań Literackich PAN, Warszawa 1999, s. VIII. 
sko - na to mianowicie, że dość szybko na łamach „Zabaw Przyjemnych i Pożytecznych" zaczęły pojawiać się głosy ludzi, z punktu widzenia których ton wygłaszanej na okoliczność powstania pisma diagnozy Albertrandiego dalece odbiegał od tego, co podpowiadała rzetelna ocena kondycji rodzimych elit tamtego czasu, z jaką to zapoznawanie się trudno byłoby tym samym ujmować przede wszystkim w kategoriach przyjemności. Zapowiadana przez założyciela „Zabaw...” różnorodność materiału literackiego mającego wypełniać ich karty realizowała się zatem pod okiem jego następcy również w sposób, którego pierwszy z nich - jak można sądzić - raczej nie przewidywał.

Bodaj najważniejszy, także ze względu na jego wartość artystyczną, spośród takich właśnie tekstów wyszedł spod pióra debiutującego niewiele wcześniej w tym samym periodyku Tomasza Kajetana Węgierskiego 5 . Znaczenie opublikowanej w siódmym tomie „Zabaw Przyjemnych i Pożytecznych” (1772 [1773]) ody O małym ludzi uczonych poważaniu ${ }^{6}$ było tym większe, że jej adresatem był sam Naruszewicz - nie tylko jedna z głównych postaci pisma od samego początku jego istnienia oraz kontynuator redakcyjnych działań swojego poprzednika, z którym zresztą łączyły go też przynależność zakonna i prowadzona w macierzystym środowisku działalność pedagogiczna; ale także człowiek cieszący się opinią ulubionego poety króla, a jednocześnie niedawny nauczyciel samego Węgierskiego i jego literacki protektor, przecierający niesfornemu młodzieńcowi, pracującemu wówczas na miano „cudownego dziecka” polskiej literatury, szlaki w świecie warszawskiej socjety. Stanowiąca o nastroju początkowego - składającego się z pięciu czterowersowych strof, pisanych, jak i pozostałe, trzynastozgłoskowcem - fragmentu tego wiersza gloryfikacja Naruszewicza-poety była w takiej sytuacji czymś naturalnym, zaś sposób, w jaki sławiono tam pisarską wszechstronność przyszłego twórcy Głosu umartych, jeśli wyróżniał się czymkolwiek na tle zalewającego ówczesną polską poezję panegiryzmu, wielokrotnie skądinąd będącego potem przedmiotem kąśliwych uwag piszącego wierszem Węgierskiego, to głównie zdradzającym miejscami językową swadę nastoletniego autora wykorzystywaniem przezeń zabiegów przypominających o... poetyckiej manierze bohatera tej laudacji.

Nie to przecież decydowało o płynącym z wiersza przekazie; nie to - co tutaj najistotniejsze - zakłócać mogło towarzyszącą jego lekturze przyjemność. Komplementy, jakimi Węgierski obdarzał porównywanego przez siebie do Orfeusza właściciela „bardonu złotogwarego”, schodziły szybko na drugi plan wobec treści stawianych Naruszewiczowi pytań, w głównej, par excellence polemicznej, części tekstu przechodzących w niewolne od sarkazmu rozpoznanie stanu polskich umysłów. Gorzkie słowa kierowane przez starościca korytnickiego do rodaków

${ }^{5}$ Debiutem tym był - przypomnijmy - przekład Porównania Karola V, cesarza, z Franciszkiem I, królem francuskim. Zob. „Zabawy Przyjemne i Pożyteczne” 1771, t. 4, cz. I, s. 8-14.

${ }^{6}$ Cytaty z tekstu za: K. Węgierski, Wiersze wybrane, wybór, oprac. tekstu i wstęp J. W. Gomulicki, Państwowy Instytut Wydawniczy, Warszawa 1974, s. 68-70. 
(nie bez przekąsu nazywanych „bitnych Sarmatów z wszech miar nieszczęśliwym plemieniem”) parę lat później, w zakończeniu wiersza Myśl moja, mogącego uchodzić za poetycki manifest jego przekonań:

Nie sądźcie, że jesteście bliscy oświecenia:

Ledwie się z barbarzyństwa dobywacie cienia ${ }^{7}$.

(w. 85-86)

- muszą jawić się w takim kontekście nie tylko jako rezultat, budzących niemałe rozczarowanie, obserwacji poety wkraczającego wtedy już w dojrzałość, a przy tym coraz bardziej skonfliktowanego ze światem stołecznej elity. Wypada je odczytywać również w perspektywie - towarzyszącej Węgierskiemu od początków jego twórczości - umiejętności przenikliwego osądu rodzimej rzeczywistości w dobie, przeprowadzanej u nas pod królewskim patronatem, oświeceniowej rewolucji.

Trudno o bardziej demaskatorskie ujęcie postępów tej ostatniej niż to, które znajdujemy w szóstej i siódmej strofie wspomnianej ody, gdzie, wzmacniając efekt emfazy, pojawiają się wspomniane wyżej pytania, o tyle dramatycznie brzmiące, o ile biorące się z dojmującej bezsilności zwolennika kulturowej zmiany:

Powiedz, co się to dzieje, że wiek tak uczony,

Tylu dzieły sławnymi, tylu ksiąg wsławiony,

Wiek, co sobie zasłużył na mądrego imię,

$\mathrm{W}$ małej przecie rozumnych ludzi ma estymie?

I tak jest ciężko na to i tak mocno chory,

Że go ni twe Satyry, ani „Monitory”

Przez ośm lat z tego błędu, z tej głupiej ślepoty

Wywieść nie mogły, kiedy trwa w niej aż dopoty?

(w. 21-28)

„Skłonność chwalebna w narodzie górować poczynająca”, która wprawiała w niekłamany zachwyt pierwszego redaktora „Zabaw...”, zderzona zostaje z podnoszonym tu brakiem szacunku dla ludzi myślących. Tamta wizja oświecenia przeradza się w swoją karykaturę. W przywoływanych przez Węgierskiego Naruszewiczowskich satyrach rozmaitego typu przerysowania, służące ujęciu pewnych zjawisk społecznych składających się na obraz „wieku zepsutego" ${ }^{8}$, wpisane były w gatunkową poetykę. Dyktowała je nie połączona z oburze-

${ }^{7}$ Cyt. za: tamże, s. 112.

${ }^{8}$ Satyra pod tym tytułem była jedną z trzech - obok Szlachetności i Glupstwa - które Naruszewicz opublikował wcześniej (wszystkie w 1771 r.) na łamach „Zabaw Przyjemnych i Poży- 
niem bezradność, lecz znamionująca pedagogiczny zapał chęć szerzenia światła, a w konsekwencji - utrwalania tego, czego coraz wyraźniejszą obecność chciał dostrzegać wśród Polaków Albertrandi. Tutaj optymizm oświeceniowych literatów-ideologów konfrontowany jest z rzeczywistością tym boleśniej, że przedmiotem uwagi mówiącego są już rezultaty przeprowadzanej przez nich na społeczeństwie obyczajowo-świadomościowej, by tak rzec, kuracji; sam zaś Naruszewicz występuje, po prawdzie, raczej w roli adwokata potrzebnego swojemu - nieoszczędzającemu otoczenia - wychowankowi niż jako ten, który pomimo posiadania licznych talentów i zasług w dziedzinie słowa mógłby przekonująco odpowiedzieć na wyrażane z podobną stanowczością wątpliwości tamtego. Nauczycielowi Węgierskiego przychodzi tu ostatecznie słuchać nie pochwał przede wszystkim, a pobrzmiewających momentami wyrzutem, cierpkich opinii o rodzimej, niepoddającej się dydaktycznej ofensywie stanisławowskiego piśmiennictwa, rzeczywistości. Tej, której ofiarą młody poeta padnie już niebawem jako autor Listu do wierszopisów i Portretów pięciu Elżbiet, narażając się na towarzyski ostracyzm, a potem także na administracyjne szykany ze strony jej prominentnych reprezentantów, zgoła inaczej rozumiejących przynależność do oświeceniowych elit.

Nim jednak w drugiej połowie dekady doszło do wydarzeń, które przyczyniły się do wyjazdu Węgierskiego z kraju, bez ogródek wskazywał on w przypominającej od pewnego momentu oskarżycielską mowę odzie to wszystko, co owemu „małemu ludzi uczonych poważaniu” sprzyjało; za najważniejszy z powodów takiego, pozostającego według niego miarą zepsucia „rodzaju ludzkiego”, stanu rzeczy uznając ufundowany na fałszywej hierarchii wartości, idący w parze z pychą egoizm. Będąca jego pochodną, daleka od szlachetności motywacja, jaką kierują się ludzie, włącznie z tymi - co szczególnie przykre - którzy „do nauk się [...] garną", niewiele ma wspólnego ze znamionującymi mądrość, zakorzenionymi w umiłowaniu cnoty: bezinteresownością i pokorą. Słyszane natomiast zewsząd rytualne niemal deklaracje przychylności dla zachodzących w duchu oświecenia przeobrażeń abstrahują w istocie od tego, co dla dokonania się fundamentalnej zmiany w myśleniu i postępowaniu Polaków najważniejsze:

Wielu chce, by w Ojczyźnie wzrost brały nauki

I żeby w niej kwitnęły wyzwolone sztuki,

Lecz żaden, widzę, na to nie daje baczenia,

Co najzdolniej pomaga do ich rozkrzewienia.

(w. 57-60 [podkr. - G.Z.])

tecznych”. Por. A. S. Naruszewicz, Satyry, wstęp i oprac. B. Wolska, Universitas, Kraków 2002, s. 179-183.

${ }^{9}$ Widzi ich poeta następująco: „A każdy z nich, czy w starym wieku, czyli młody, / Pragnie szczęścia dla siebie lub jakiej nadgrody” (w. 55-56). 
Tym czymś, czego istnienie uprawnia Węgierskiego do formułowania podobnie kategorycznych sądów, jest dostrzegany przez niedawnego ucznia Naruszewicza, niezamierzającego się kryć z kontestacją pseudooświeceniowych porządków, fetysz własnej wielkości, nakazujący ludziom traktować wiedzę instrumentalnie, a nie jako sposób poznawania świata i doskonalenia człowieka. Zamykające jego wyznanie ${ }^{10}$ - wpadające $\mathrm{w}$ tonację dziękczynienia, korespondujące tym samym z wypełniającą początkowe strofy wiersza apoteozą tego, „co Pegazem jeździ” - słowa kierowane do „przezacnego męża” nie mogą przesłonić faktu, iż w drukowanym na łamach „Zabaw Przyjemnych i Pożytecznych” tekście poetycki czeladnik potraktował ich redaktora nie tylko jak swojego mistrza. Schlebiając Naruszewiczowi i dzieląc się z nim w zaufaniu pełnymi sceptycyzmu spostrzeżeniami, jego także w swej młodzieńczej bucie nie zwalniał - jak się zdaje - od odpowiedzialności za trwanie rodaków w „głupiej ślepocie”, z wyprowadzaniem z której najwyraźniej nie radzili sobie w opinii przyszłego twórcy Organów nawet stanisławowscy luminarze.

Węgierski kilkakrotnie jeszcze publikował w „Zabawach...” wierszowane utwory swojego autorstwa. Zważywszy jednak, że mowa głównie o bajkach (Kozłowie, Róża i lilija, Dwa strumyki) i sielankach (Hilas i Celeryna) ${ }^{11}$, nie znajdziemy wśród nich takich, których charakter czy nastrój pozwalałaby mówić o eksponowaniu tego, co z różnych powodów bolesne, drażliwe czy zawstydzające, kosztem przekazu mieszczącego się w pojęciu literackiej zabawy, nade wszystko sprzyjającego odczuwaniu przez czytelnika rozmaicie pojmowanej przyjemności. Także tej - jak w przypadku Kozłów, mających zapewne w tle doświadczenie pierwszego rozbioru - która wynikałaby z obcowania z odległą wprawdzie od beztroskich ujęć świata, ale za to klarownie wyłożoną, tu uzmysławiającą wartość „,spokojnego bycia”, życiową prawdą. Na wiersze, których treścią, klimatem i tonem zapracować miał z czasem Węgierski na status enfant terrible polskiej poezji tamtej doby, także w piśmie redagowanym przez adresata jego debiutanckiej ody miejsca już nie było.

Bez trudu znajdziemy tam wszakże teksty innych autorów pisane w aurze niekojarzącej się z pewnością nawet ze stosunkowo szeroko definiowaną rozrywką intelektualną - skłaniające nie tyle do delektowania się słowem, ile mogące ze względu na sposób potraktowania podejmowanej w nich problematyki niepokoić, przejmować, wywoływać wzburzenie. Można by do tej grupy zaliczyć takie na przykład wiersze, jak Oda do pokoju Józefa Epifaniego Minasowicza (1772), Oda do sprawiedliwości Józefa Kazimierza Świętorzeckiego (1774) czy napisana przez samego Jana Albertrandiego Oda do czasu $(1774)^{12}$, powstałe - na co wyraźnie wskazuje nie tylko ostatnie z wymienionych nazwisk - w kręgu autorów, których związki z „Za-

${ }^{10}$ Jawności podmiotu autorskiego nie sposób tu przecież kwestionować.

${ }^{11} \mathrm{Na}$ temat szczegółów dotyczących ich ukazywania się zob. E. Aleksandrowska, dz. cyt., s. 175.

${ }^{12}$ Fragmenty tych tekstów (pierwszy z nich, warto uściślić, to parafraza Ode à la paix Pierre'a Ronsarda) cyt. za: „Zabawy Przyjemne i Pożyteczne” (1770-1777). Wybór, s. 287-291, 296-298, 
bawami..." i patronującym temu pismu środowiskiem były znacznie silniejsze niż w przypadku Węgierskiego. Nie bez przyczyny wszystkie one pomieszczone zostały przez Barbarę Wolską w antologii wierszy politycznych pierwszej połowy lat siedemdziesiątych XVIII stulecia ${ }^{13}$, nie są to bowiem utwory, gdzie - jak mogłyby sugerować ich tytuły - nie stroniąc od wzniosłości i poetyckiego, apoteozie służącego, wyrafinowania, operowano by abstrakcyjnymi, mogącymi przywodzić na myśl rozważania natury filozoficznej, ujęciami tytułowych „bohaterów”. W tle każdego z tych tekstów, za wypełniającymi je patetycznymi apostrofami i tworzącymi egzemplaryczną warstwę monologu lirycznego obrazami, odwołującymi się - w zgodzie z nakazami stylistycznej stosowności - bądź do mitu, bądź do dziejów starożytnych Greków czy Rzymian (Minasowicz, Albertrandi); ale też za łączącymi lamentację z pełnymi potępienia, niekryjącymi emocjonalnego zaangażowania podmiotu wypowiedzi, apelami o poskromienie „dumnego szaleństwa” rodzącego bezprawie (Świętorzecki) - znajdują się przecież realia stanisławowskiej Polski, trawionej wewnętrznymi konfliktami, doświadczającej rozbiorowego upokorzenia, niepotrafiącej poradzić sobie z panoszącą się, podważającą zaufanie do państwa, prywatą.

Nie trzeba było, jak skazany niewiele później na więzienie twórca Organów, samemu być ofiarą tej ostatniej, by dostrzegać potrzebę formułowania tak rozpaczliwie brzmiących pytań i przypominania o uzasadniających je, jakże mało przyjemnych zjawiskach z życia królewskich poddanych:

Święta sprawiedliwości! Kędyż swe mieszkanie

Założyłaś, wyszedłszy od nas na wygnanie?

Oddawszy w chciwe ręce srogi miecz i szale,

By je zmienny człek trzymał ślepo i niestale?

$[\ldots]$

Na krwawy płacz niewinnych zatykając uszy,

Nielitościwie wtrącał do ciemnej katuszy,

Że kto drogo opłacić swej nie może sprawy,

Dźwigał przeto na sobie dekret niełaskawy.

(w. 5-8, 13-16)

Sprawiedliwość, do której niemal wyzywająco zwraca się podmiot mówiący w wierszu Świętorzeckiego, jest sprawiedliwością mającą dowieść swego istnienia właśnie tutaj, „na naszej [...] ziemi”. Zarówno sławiony w odzie Minasowicza

292-294. Tam gdzie było to konieczne, dokonano korekt w zakresie interpunkcji i ujednolicono pisownię.

${ }^{13}$ Zob. Wiersze polityczne pierwszego rozbioru i sejmu delegacyjnego 1772-1775, oprac. B. Wolska, Wydawnictwo Sejmowe, Warszawa 2001. 
pokój, jak i czas - adresat próśb określających uczuciową atmosferę wiersza Albertrandiego - również przyzwane zostały nie z chęci unoszenia się nad humanistycznymi wartościami jednego i wszechmocą drugiego, ale - co wydaje się oczywiste - ze względu na dokonującą się wówczas degradację polskiej rzeczywistości, nijak nietłumaczącą oświeceniowego triumfalizmu, za którego objaw mogłyby też przecież uchodzić wcześniejsze o ledwie kilka lat stwierdzenia ,inicjatora i projektodawcy”14 „Zabaw Przyjemnych i Pożytecznych”.

Osobną kwestią jest to, że tak wyraźnie widoczne w każdym z tych tekstów wychodzenie poza treści ewokowane przez dwa początkowe człony tytułu Naruszewiczowskiego periodyku nie łączyło się z próbą aluzyjnego choćby wskazania na współodpowiedzialność panującego i jego otoczenia za przedstawiany wierszem stan rzeczy. Ani w słyszanych u Minasowicza zawodzeniach nad „ludu strapionego jękami”, ani w łączonych z władzą czasu nad ludzkimi losami życzeniach „wygubienia” pamięci o „sprawcach smutnej doli” narodu (nazywa ich Albertrandi „wyrodkami plugawymi, / Co skrzywdziły społeczność dla własnego zysku”), ani wreszcie w wierszowanych tyradach Świętorzeckiego, motywowanych rozchodzącym się po Rzeczpospolitej „krwawym płaczem niewinnych” - przyjemności czytającego nie zakłócał, bo też z racji usytuowania pisma w środowisku przykrólewskim nie mógł zapewne zakłócać, pozbawiony upiększeń obraz Stanisława Augusta, powolnego przedstawicielom petersburskiej monarchini, wyrzekającego się tym samym realnego wpływu na sytuację w tracącym terytorialną integralność, zanarchizowanym państwie. Jemu Polacy mieli zawdzięczać „nauki, obyczaje, kunszta i rozkoszy" - to, co uprawniało Albertrandiego-poetę do sięgnięcia po pompatyczne stwierdzenie, że „smak do dobrego sławi wolą panowania”. Jego przeciwnikom natomiast - wśród których, jak wiadomo, szczególne miejsce na łamach „Zabaw...” zajmowali konfederaci barscy - dojmujące przekonanie, iż „Zazdrość z dzikością krainy pustoszy”.

Podobnie dychotomiczne ujmowanie polskich spraw w tekstach zamieszczanych w elitarnym stanisławowskim magazynie najostrzej chyba rysuje się tam, gdzie powraca sprawa porwania króla przez barszczan w listopadzie 1771 roku. Wśród wielu odwołujących się do tego zdarzenia utworów poetyckich (w tym również autorstwa samego Naruszewicza) znajdujemy także wiersz Antoniego Korwina Kossakowskiego Do narodu i potomności, wyróżniający się nie tylko długością (liczy aż 250 wersów), ale i literackim profilem samej wypowiedzi ${ }^{15}$. „Okropny

${ }^{14}$ E. Aleksandrowska, dz. cyt., s. V.

${ }^{15}$ Zauważała to już Irena Turowska-Barowa, pierwsza monografistka „Zabaw...”, podkreślając, że pomiędzy innymi tekstami powstałymi w natychmiastowej reakcji na „,nieudany zamach konfederatów barskich” ten właśnie „odznacza się największą siłą uczucia” (,Zabawy Przyjemne i Pożyteczne" (1770-1777). Ze studiów nad literatura stanisławowska, Drukarnia W. L. Anczyca i S-ki, Kraków 1933, s. 27). Cytaty z tekstu za: „Zabawy Przyjemne i Pożyteczne” (1770-1777). Wybór, s. 267-277. 
przypadek" (wyrażenie to pojawia się w podtytule), o którym tu mowa, przedstawiony został bowiem przez królewskiego sekretarza nie tyle - jak chciał to widzieć Julian Platt - w konwencji „kroniki wypadków” "16, ile jako przedmiot niestroniącej od sensacyjności, wykorzystującej elementy poetyki grozy, opowieści, gdzie żywioł epicki przenika się nieustannie z ujawniającym emocjonalne zaangażowanie opowiadającego przekazem natury perswazyjnej, służącym, rzecz jasna, wyniesieniu na piedestał cudownie ocalonego z woli Boga władcy, tak haniebnie potraktowanego wcześniej przez „świętokradzką zgraję”. Tego, jak autor wiersza od samego początku zabiega o stworzenie odpowiedniego nastroju, sprzyjającego budowaniu fabularnego napięcia, a w rezultacie unaocznianiu zła, jakiego doświadczyła Rzeczpospolita z rąk tych, którzy zamachnęli się na królewski majestat, dowodzi choćby sposób ukazywania przez niego scenerii tamtych wydarzeń:

Noc była, i okropne rozpostarłszy cienie,

Sen w oczy, na języki zlewała milczenie.

Noc była, lecz niedługo, jeszcze swoje konie

W podziemnej Febus pławił, ogniem tchnący, stronie.

$[\ldots]$

Noc była, co w swych cieniach występków szkarady

I wybladłe wszech zbrodni ukrywa gromady,

Bo się w ten czas tu, ówdzie, snują bez bojaźni,

W ten czas się bezpiecznymi mściwej sądzą kaźni,

$\mathrm{W}$ ten czas gniew rozjuszony, w ten czas zjadłość wściekła

Z zgrają na świat bezecnych sióstr wylata z piekła.

$[\ldots]$

Noc była: ach! na samo nocy tej wspomnienie

Zimny pot czoło zbroczył, strach i zadumienie

Ciepłą w żyłach krew zwarły, lice marmur blady

Pokrył. Ledwo zostały, żem jeszcze żyw, ślady.

(w. 1-4, 9-14, 17-20)

Kształtowaną w taki sposób, z wykorzystaniem retorycznego efektu gradacji, aurę tego monologu znacząco dookreślają powtarzające się w jego wstępnej partii, nawiązujące do topiki epickiego otwarcia, dramatyczne zwroty do „gęśli mojej” - przenikający tę część utworu niepokój („Ledwom brzęknął, od strachu zadrżały twe strony!") ilustrować ma złowrogą nadzwyczajność całej, przybliżanej rodakom ku przestrodze, sytuacji. Odciska się on potem, co istotne, na kształcie tego wierszowanego, wbudowanego przez poetę-panegirystę w patriotyczny apel,

16 „Zabawy Przyjemne i Pożyteczne” (1770-1777). Wybór, s. 268. Skądinąd, jako „plastycznie wierszowana" oceniana jest tam ona wysoko. 
opowiadania. Prowadzona tu relacja z wydarzeń towarzyszących uprowadzeniu króla jest przecież specyficzna także dlatego, że niemal przez cały czas wchodzi w kolizję z klarownością uporządkowanego, niezdradzającego nastawienia mówiącego, wywodu. Jej charakterystyczną, dyktowaną wzburzeniem oddanego Stanisławowi Augustowi obywatela, nieciągłość określają przy tym tyleż właściwe formule oracji, uderzające górnością apostrofy („O, obelgo narodu! pięknej chwały skazo! / O, piątno! O, wiekami niezatarta zmazo!"), ile przetykanie tekstu nadającymi mu lirycznego również wymiaru, bo sprzyjającymi subiektywizacji ujęcia, zabiegami językowymi, pozwalającymi samemu opowiadaczowi stać się w pewnym sensie uczestnikiem przypominanych w wierszu wypadków - kimś, kto, znajdując się $\mathrm{w}$ ich pobliżu, wchodzi niejako w rolę królewskiego anioła stróża. Jest nim wtedy, gdy próbuje ostrzec władcę przed tymi, którzy na niego „śmiertelny zamach żelazem gotują", a potem ponagleniami zdaje się zawstydzać bezradną wobec napastników monarszą służbę:
Ach! Schroń się, miły Panie! Wszakże twoje życie
Jest życiem wszystkich. Cóż to? Pana nie bronicie,
Wierna sług garstko? Kędyż szlachetniejsze pole
Krew wylać, życie tracić, jeśli nie za Krole?;
(w. 45-48)

ale i wówczas, kiedy stara się wzbudzić poczucie winy w pilnującym króla po porwaniu człowieku, nakłaniając go do wypowiedzenia lojalności towarzyszom złej sprawy:
O, stróżu! Cóż cię jeszcze, że się wzdrygasz, mami,
Królobójstwo lepszymi zgładzić usługami?
Przysięga na przeszkodzieć? Jestże, co by srożej
Jak ta przysięga mogła lżyć majestat Boży?
Wypełnić ją, jest zbluźnić Bogu; obietnicę
Dotrzymać, jest na niego podnosić prawicę.
(w. 117-122)

Możność przenoszenia się na miejsce zdarzeń wraz z podmiotem takich jak te wypowiedzi powodowała niewątpliwie, że ich obraz - także, dodajmy, ze względu na wykorzystywanie przez autora formy praesens historicum - stawał się w oczach czytelnika bardziej sugestywny. Powstające w ten sposób wrażenie trudno byłoby jednak łączyć bez zastrzeżeń z rodzącą się w obcowaniu z poezją przyjemnością. Zwłaszcza że również w końcowej, nienarracyjnej już części wiersza, następującej po ukazaniu przez nieunikającego hiperbolizacji poetę wizji powrotu króla do Warszawy („, , nad dzień biały w nocy jaśniejsza godzino!”), 
„okropne tony”, których źródłem jest tam strach przed wyrokami, jakie wydać może tytułowa potomność na pokolenie „królobójców”, nierzadko „głuszą wdzięki przyjemne słodkobrzmiącej strony" ${ }^{17}$. Słowa o „wyrodnym plemieniu”, które „krwią spluskało własnej jeszcze matki brzemię”, zasługując tym samym na miano „zjadłych padalców”18; czy też ujęty w sekwencję demaskatorskich pytań katalog domniemanych win Stanisława Augusta ${ }^{19}$ - z wydawanymi przez nią dźwiękami wiele wspólnego nie miały.

Tekstu, w którym w taki sposób poruszano podobnie bolesną problematykę, nie sposób było traktować w kategoriach zbliżonych do tego, czego znaczenie dla stanu ludzkiego ducha podkreślał potem z prostotą jeszcze jeden z drukujących na łamach „Zabaw...” poetów - Jan Haraburda, tak oto rozpoczynając wiersz Chory pisze o śpiewaniu, przypominający w dalszej części oparte na składniowych paralelizmach, chętnie operujące rozbudowanym wyliczeniem, barokowe jeszcze rymy:

Nieźle pośpiewać czasem sobie gwoli, W pracy, w ucisku lub kiedy co boli ${ }^{20}$.

(w. 1-2)

Tak jak niemało spośród ukazujących się w Naruszewiczowskim piśmie utworów, Do narodu i potomności - choć służący w zamyśle Kossakowskiego powszechnemu pożytkowi - nie mógł być miły dla ucha ówczesnego odbiorcy. Inaczej niż owo „śpiewanie”, nie przynosił bowiem ulgi, a przeciwnie: wstrząsając zmuszał czytelnika odczuwającego łączność z narodową wspólnotą do niepozbawionej zatroskania refleksji nad jej, skażonym teraz działaniami „wściekłych zdrajców", dziedzictwem. Wprawdzie pozostający królewskim faworytem redaktor elitarnego periodyku, twórca powstałej w tym samym czasie ody Do ojczyzny. Z okazji niestychanego przypadku Jego Królewskiej M[oś]ci, nie widział bez wątpienia niczego zdrożnego w ukazywaniu konfederatów barskich w ten właśnie sposób, ich, rysowane w mających podobną wymowę tekstach, sylwetki musiały jednak sprawiać, że jako następca Albertrandiego wielokrotnie oddalał się od „zabawowej” formuły pisma. Paradoksalnie, wiersze rozmaitych apologetów

${ }^{17} \mathrm{~W}$ finale tłumaczyć zdaje się zresztą z tego sam mówiący („Gęśli moja, zamilknij [...]”), pragnąc - mimo wszystko - obwieścić światu, że „Bóg sam, Pan ten, nie głosem, lecz więcej, bo cudem / Dał znać, że Król jest Królem nad wiernym mu ludem” (w. 249-250).

${ }^{18}$ Nie kusząc się o stylistyczną lekkość, autor dba jednocześnie o wyrazistość semantycznych opozycji służących uwypukleniu duchowej brzydoty nazywanych tak ludzi: „polska krew” - „sprośna jucha”, „najświętsze ustawy” - „wściekłe sprawy”, „piękna sława” - „dzika szkarada”.

${ }^{19}$ „Zły król, za co? Że prawnie z narodu wybrany? / Że w nim każdy sąd, prawdę wypatrzył poddany, / Że każdy ojcem potrzeb swych Króla mianuje? / Że przemożność, jak przedtem, w stanach nie góruje? / Zły król, za co? Czy, że się z krwi Jagiełłów rodzi?” (w. 221-225).

${ }^{20}$ Cyt. za: „Zabawy Przyjemne i Pożyteczne” (1770-1777). Wybór, s. 359. 
władcy wpływały na to w nie mniejszym z pewnością stopniu niż utwory tych, którzy - jak Węgierski - szybko dostrzegli skazy również na wizerunku ludzi chcących uchodzić za koryfeuszy polskiego oświecenia.

\section{Bibliografia}

Aleksandrowska Elżbieta, „Zabawy Przyjemne i Pożyteczne” 1770-1777. Monografia bibliograficzna, Wydawnictwo Instytutu Badań Literackich PAN, Warszawa 1999.

Naruszewicz Adam Stanisław, Satyry, wstęp i oprac. B. Wolska, Universitas, Kraków 2002.

Węgierski Kajetan, Wiersze wybrane, wybór, oprac. tekstu i wstęp Juliusz W. Gomulicki, Państwowy Instytut Wydawniczy, Warszawa 1974.

Wiersze polityczne pierwszego rozbioru i sejmu delegacyjnego 1772-1775, oprac. Barbara Wolska, Wydawnictwo Sejmowe, Warszawa 2001.

„Zabawy Przyjemne i Pożyteczne” (1770-1777). Wybór, oprac. i wstęp Julian Platt, Zakład Narodowy im. Ossolińskich - Wydawnictwo, Wrocław 1968.

Turowska-Barowa Irena, „Zabawy Przyjemne i Pożyteczne” (1770-1777). Ze studiów nad literatura stanisławowska, Drukarnia W. L. Anczyca i S-ki, Kraków 1933.

Grzegorz Zając

(Not)enjoyable poetry games under the watchful eye of Adam Naruszewicz

(Summary)

Words of Jan Albertrandi which he said in 1770, explaining the reasons for publishing the magazine 'Zabawy Przyjemne i Pożyteczne', expressed an enthusiasm about the possibility of achieving by Poles the state of the spiritual and intellectual maturity in a short time. The result of such attitude of the editor was his willingness to provide to potential readers of the magazine the entertainment meeting their expectations, characterizing post-Sarmatian customs. Quite quickly however in ' $\mathrm{Za}$ bawy...' there appeared the opinions of people whose point of view was different than that one of Albertrandi, because of their critical assessment of the condition of Polish Enlightenment elites. Perhaps the most important of such voices was a text of very young poet Tomasz Kajetan Węgierski. The significance of his ode (About disrespect towards learned men) was largely the result of the fact that it was addressed to Adam Naruszewicz, not only one of the leading figures of the magazine from the very beginning of its existence but also the man being the favourite poet of King Stanisław August Poniatowski. The undertone of this work was harmonizing, paradoxically, to the meaning of numerous poems, also printed in that time in 'Zabawy...', directed against Bar confederates and written in the circle of people close to the king, like Antoni Korwin Kossakowski, the author of the poem entitled To the Nation and Posterity.

Keywords: the Enlightenment; the history of Polish literature; poetry; the magazine 'Zabawy Przyjemne i Pożyteczne'; Jan Albertrandi; Adam Naruszewicz; Tomasz Kajetan Węgierski; the Confederacy of Bar

Słowa kluczowe: oświecenie; historia literatury polskiej; poezja; „Zabawy Przyjemne i Pożyteczne"; Jan Albertrandi; Adam Naruszewicz; Tomasz Kajetan Węgierski; konfederacja barska 